\title{
The Canadian Public Domain: What, Where, and to What End?
}

\author{
Carys J. Craig \\ Osgoode Hall Law School of York University, ccraig@osgoode.yorku.ca
}

\section{Source Publication:}

Canadian Journal of Law and Technology

Follow this and additional works at: https://digitalcommons.osgoode.yorku.ca/scholarly_works

Part of the Intellectual Property Law Commons

\section{c) (i) $(9)$}

This work is licensed under a Creative Commons Attribution-Noncommercial-No Derivative Works 4.0 License.

\section{Recommended Citation}

Craig, Carys J. "The Canadian Public Domain: What, Where, and to What End?." Canadian Journal of Law and Technology, 7 (2010): 221.

This Article is brought to you for free and open access by the Faculty Scholarship at Osgoode Digital Commons. It has been accepted for inclusion in Articles \& Book Chapters by an authorized administrator of Osgoode Digital Commons. 


\title{
The Canadian Public Domain: What, Where, and to What End?
}

\author{
Carys J. Craig* \\ "[A] place like home, where, when you go there, they have to take you in \\ and let you dance" \\ David Lange, "Re-Imagining the Public Domain"1
}

\section{INTRODUCTION}

\section{(a) What and Where is the Public Domain?}

What is the Canadian "public domain"? The short answer is that the public domain - like almost everything else in intellectual property law — is a metaphor. And so, perhaps it would be more appropriate to ask: "what does the 'public domain' mean?" The response, however, may be similarly unsatisfactory: it means whatever we want it to mean. Far from being either trite or obtuse, this answer reveals the fundamental role and critical characteristic of the public domain in intellectual property policy: the "public domain" is a political concept that has, over the past thirty years or so, been quite deliberately loaded with sufficient normative and rhetorical force that it can be effectively employed in critical response to the rhetoric of property that drives the IP-expansionist agenda.

In this article, I explore the important body of scholarship that has emerged over this time on the substance, nature, and role of the public domain. I offer some concrete definitions of the public domain in the copyright context, identify some ongoing sources of debate in the literature, and highlight some particularly significant voices in public domain discourse. In doing so, my aim is twofold: first, I mean to present a fairly comprehensive, but concise, review of this academic movement that has been directed towards substantiating and politicizing the concept of the public domain; and second, I hope to re-situate it in the Canadian context in which the concept has remained relatively underdeveloped, but where it has a crucial and timely role to play in the evolution of copyright law and policy.

Ultimately, I suggest that the public domain is necessarily protean in nature, and that this is the source of its power. Rather than asking "what is the public domain?", we should ask ourselves what it is that we need it to be. For my part, I believe that we need a public domain that reflects and protects the dialogic processes of culture in the face of increasingly restrictive intellectual property

* LL.B. (Hons), LL.M., S.J.D., Associate Professor of Law, Osgoode Hall Law School, York University. A version of this article is forthcoming in Rosemary J. Coombe \& Darren Wershler, eds., "Dynamic Fair Dealing: Creating Canadian Culture Online."

${ }^{1}$ David Lange, "Reimagining the Public Domain" (2003) 66 Law \& Contemp. Probs. 463. 
structures. And so, to the question "where is the public domain?", we might say that it is both nowhere and everywhere: nowhere because it is best understood merely as metaphor and not as some sort of metaphysical territory or geographically separate preserve; everywhere because it is anywhere where people create and communicate. ${ }^{2}$

\section{(b) Recognizing the Public Domain}

The existence of the public domain can be traced back to the beginning of copyright law in the sense that the limited time accorded to the author's right effectively brought it into being. ${ }^{3}$ As Mark Rose notes, however, we must distinguish between "the fact of the public domain and what might be called the discourse of the public domain - that is, the construction of a legal language to talk about public rights in writings." 4 The term "public domain" is a relatively recent entrant into common law copyright discourse, appearing as it did only in the late nineteenth century. The "affirmative discourse" 6 of the public domain - which seeks to render the public domain "a positive and prominent part of the social and cultural landscape" $" 7$ and ascribe to it an expanding normative role in intellectual property policy - is an even more recent phenomenon, the origin of which is widely attributed to a seminal essay by David Lange in $1981 .{ }^{8}$ In response to the emergence of new "publicity rights" in the US courts, Lange cautioned against the ad hoc proliferation of "property-equivalent theories" 9 and called for such emergent intel-

2 Julie E. Cohen, "Copyright, Commodification, and Culture: Locating the Public Domain" in L. Guibault \& P.B. Hugenholtz, eds., The Future of the Public Domain (Netherlands: Kluwer Law International, 2006) 121 at 157 - "If one asks where the common in artistic culture may be found, the answer, quite simply, is that it is everywhere the public is."

3 Mark Rose, "Nine-Tenths of the Law: The English Copyright Debates and the Rhetoric of the Public Domain" (2003) 66 Law \& Contemp. Probs. 75 at 76 - "copyright and the public domain were born together." See also Ray L. Patterson \& Stanley W. Lindberg, The Nature of Copyright: A Law of User's Rights (London: The University of Georgia Press, 1991) at 29-31; Cf. Ronan Deazley, Rethinking Copyright: History, Theory, Language (Northampton: Edward Elgar, 2006) at 108-109 - "While the rhetoric of copyright and the public domain may well be interdependent, if historically contingent, the actuality of the public domain did in fact pre-date copyright."

4 Rose, ibid. at 87.

5 Jane C. Ginsburg, "Une Chose Publique'? The Author's Domain and the Public Domain in Early British, French and U.S. Copyright Law" (2006) Cambridge L.J. 636 at 637.

$6 \quad$ Rose, supra note 3 at 87.

7 Ibid.

8 David Lange, "Recognizing the Public Domain" (1981) 44 Law \& Contemp. Probs. 147; See e.g. James Boyle, "The Second Enclosure Movement and the Constitution of the Public Domain" (2003) 66 Law \& Contemp. Probs. 33 at 59. 
lectual property interests to be offset by an "equally deliberate recognition of individual rights in the public domain." 10

At that time, Lange professed to be less concerned by the law of copyright, which seemed to him to be "in a state of reasonable equilibrium." 11 The extent to which Lange's call has been heeded by copyright scholars in recent years is attributable in large part to the disruption of this apparent equilibrium in the face of the digital revolution. ${ }^{12}$ As copyright law has struggled to adjust to the realities of a shifting cultural environment in which new technologies breed new modes of productivity, consumption, and exchange, the public domain has indeed been "pressed into service." 13 Perhaps Edward Samuels was correct in his insistence, even back in 1993, that it was already "a little late in the game to be developing a "theory of the public domain", 14 but he was also right to imagine that those who find themselves continually arguing for limitations on the expanding scope of intellectual property may come to need a rallying cry; ${ }^{15}$ for better or worse, that rallying cry has become "the public domain."

In Canada, the cry has remained faint and distant - until now. Typically, references to the public domain in Canadian jurisprudence have been rare and uninspired, and the prevailing assumption is that the public domain is no more than intellectual property's leftovers - the crumbs that remain once its appetite is satisfied. Teresa Scassa is right to observe that, thus constituted and constructed only in the negative, Canada's public domain is "a fragile thing" 16 whose scope can be expanded or shrunk by either legislative enactment or judicial interpretation. Perhaps our complacency in this regard reflects the absence of any radical change in the form or substance of our copyright law since $1924 .{ }^{17}$ If so, the time for complacency is over and the rallying must begin: with copyright reform looming and the expansionist agenda dominating political discourse, Canada sorely needs a positive account of the public domain.

$10 \quad$ Ibid. at 147.

11 Ibid. at 157.

12 See e.g. Lawrence Lessig "Re-Crafting a Public Domain" (2006) 18 Yale J. L. \& Human. at 56. Cited in Rebecca Tushnet, "Domain and Forum: Public Space, Public Freedom" (2007) 30 Colum. J.L. \& Arts at 106 — "There is a public domain, but it is small, relative to its history, and it is shrinking. Digital technology will only speed its decline. And because most are oblivious to the particular threat that digital technology poses for the public domain, the prospects for reversing this trend are not promising." Lange, supra note 1 at 466.

14 Edward Samuels, "The Public Domain in Copyright Law" (1993) 41 Journal of the Copyright Society 137 at 182 .

15 Ibid., at 150.

16 Teresa Scassa, "Table Scraps or a Full Course Meal? The Public Domain in Canadian Copyright Law" in McGill University Faculty of Law, ed., Intellectual Property at the Edge: New Approaches to IP in a Transsystemic World - Meredith Lectures (Cowansville: Qc.: Yvon Blais, 2007) 347 at 348.

17 Margaret Ann Wilkinson, "National Treatment, National Interest and the Public Domain” (2003-2004) 1 University of Ottawa Law \& Technology Journal 23 at 31. 
Fortunately, the Supreme Court of Canada laid the groundwork for renewed interest in the public domain in its important ruling in Galerie d'Art du Petit Champlain inc. $c$. Théberge. ${ }^{18}$ Justice Binnie, writing for the majority, implied a dynamic role for the public domain in the newly articulated "copyright balance"19 when he wrote: "Excessive control by holders of copyrights and other forms of intellectual property may unduly limit the ability of the public domain to incorporate and embellish creative innovation in the long-term interests of society as a whole, or create practical obstacles to property utilization."20 Thereafter, the unanimous Court in CCH Canadian Ltd. v. Law Society of Upper Canada expressly acknowledged "society's interest in maintaining a robust public domain that could help foster future creative innovation." 21

Incorporate, embellish, utilize, create, and innovate. The vision of the public domain that has thus emerged from Canadian jurisprudence appears to be one of a vibrant cultural space that facilitates exchange and transformation, inspiration and innovation, and thereby serves the public interest. But if the goal of a robust public domain is to survive the next round of legislative reform, its shape and scope are in dire need of both definition and deference.

\section{MAPPING THE (MANY) PUBLIC DOMAIN(S)}

\section{(a) The Core of the Public Domain}

The term "public domain" is most commonly and least controversially used to describe the sphere in which contents are free from copyright or other intellectual property rights. No one individual can claim any better right than any other to use or control intangible expression in the unowned public domain. ${ }^{22}$ In the spectrum of definitional approaches to the public domain, this one is overtly - perhaps overly - legalistic, but indubitably accurate. Perhaps the most typical example of material in this domain is that of a work whose protection has expired, ${ }^{23}$ or a work not deserving of protection because it fails to meet the legally prescribed minimum

18 Galerie d'art du Petit Champlain inc. c. Théberge, 2002 CarswellQue 306, 2002 SCC 34, [2002] 2 S.C.R. 336 (S.C.C.) [Théberge].

19 Ibid. at para. 30 - Binnie J.: "The Copyright Act is usually presented as a balance between promoting the public interest in the encouragement and dissemination of works of the arts and intellect and obtaining a just reward for the creator."

Ibid. at para. 32 .

21 CCH Canadian Ltd. v. Law Society of Upper Canada, 2004 SCC 13, [2004] 1 S.C.R. 339 (S.C.C.) $[\mathrm{CCH}]$.

22 Deazley, supra note 3 at 107.

23 The following is a fairly typical example of a lay definition of the public domain: "[t]hat which by its nature might have been or once was protected by copyright, patent, or trademark, but which is now unprotected and open to use by anyone. For example, a book written 100 years ago, which was once copyrighted, but is now unprotected because its copyright period has run out" - David Brownstone \& Irene M. Franck, The Dictionary of Publishing (New York: Van Nostrand Reinhold, 1981), cited in Wilkinson, supra note 17 at 28 . In Canada, copyright typically expires 50 years after the death of the author - Copyright Act, R.S.C. 1985, c. C-42, s. 6 [Copyright Act]. 
requirements. ${ }^{24}$ Works thus devoid of intellectual property protection belong in what Pamela Samuelson calls the "core" of the public domain. ${ }^{25}$

As Jessica Litman reminds us, however, the class of works not subject to protection is perhaps "the least significant portion of the public domain." 26 Also within the "core" of the public domain are "those aspects of copyrighted works that copyright does not protect." 27 The line between public and private should therefore be conceptualized as a divide internal to the work; it traverses the work, separating protectable from non-protectable elements. Consider copyright's foundational ideaexpression dichotomy: ideas, concepts, and theories are excluded from copyright's protective sphere and belong to the public domain - only the expression of those ideas is copyrightable and may be subject to private control. As Justice Learned Hand explained in Nichols v. Universal Pictures Corp. ${ }^{28}$ because ideas or generalized abstractions are beyond the purview of copyright, the author's right will not cover "everything that might be drawn" from a work; its content always belongs, to some extent, to the public domain. ${ }^{29}$

Similarly, systems and methods belong in the public domain notwithstanding that the description or illustration of a system or method may be protectable expression. As Lord Justice Davey explained in Hollinrake v. Truswell, "[n]o doubt one may have copyright in the description of an art; but, having described it, you give it to the public for their use; and there is a clear distinction between the book which described it, and the art ... which is described." 30 Facts, information and data are non-copyrightable and remain in the public domain although the selection or ar-

24 In the copyright context, a work may fail to meet the threshold requirement of originality (e.g. CCH, supra note 21) or may not quality as literary, dramatic, musical or artistic expression (e.g. Cuisenaire v. South West Imports Ltd. (1967), [1968] 1 Ex. C.R. 493, 54 C.P.R. 1 (Can. Ex. Ct.); affirmed (1968), 1968 CarswellNat 56 (S.C.C.) [Cuisenaire]). See Copyright Act, ibid. at s. 5.

25 Pamela Samuelson, "Mapping the Digital Public Domain: Threats and Opportunities" (2003) 66 Law \& Contemp. Probs. 147 at 151.

26 Jessica Litman, “The Public Domain” (1990) 39 Emory L.J. 965 at 974.

27 Ibid.

28 Nichols v. Universal Pictures Corp., 45 F. 2d 119 (2d Cir., 1930) [Nichols].

29 Justice Learned Hand wrote, ibid. at 12-13: "[the author's] copyright did not cover everything that might be drawn from her play; its content went to some extent into the public domain. We have to decide how much, and while we are as aware as any one that the line, wherever it is drawn, will seem arbitrary, that is no excuse for not drawing it."

30 Hollinrake v. Truswell, [1894] 3 Ch. 420 (Eng. C.A.). As Justice Paper evocatively explained in Cuisenaire v. Reed, [1963] V.R. 719: "[w] ere the law otherwise . . everybody who made a rabbit pie in accordance with the recipe of Mrs. Beeton's Cookery Book would infringe the literary copyright in that book." Quoted in Cuisenaire, supra note 24. Relatedly, utilitarian articles belong in the public domain (or subject only to patent law), although any "severable" literary or artistic expression may be protected. Thus, in Hollinrake, a dressmaker's sleeve chart was denied copyright protection on the grounds that it was a "measuring apparatus." 
rangement of data may be protected as original expression. ${ }^{31}$ Finally, where there is only one, or a limited number of ways in which to express an idea, system, or fact, the expression itself may continue to reside in the public domain in order to ensure that the unprotectable elements are not indirectly subject to private control. ${ }^{32}$

Even this legalistic definition reveals the inevitable indeterminacy of the public domain, and the extent to which its boundaries resist concretization. Copyright's doctrines are simple enough to state, but their practical application is often complex, context-specific, and, therefore, inherently unpredictable. It is easy enough to say that ideas belong in the public domain, but far harder to delineate the contours of expression and the point in a series of abstractions at which protection runs out. ${ }^{33} \mathrm{We}$ can say that facts belong in the public domain, but struggle to distinguish a merely industrious collection from a selection involving more than a trivial level of skill and judgment. ${ }^{34}$

As Ronan Deazley concedes, "it will always remain impossible to determine with accuracy, at any given time, that which is public domain and that which is not." 35 The doctrinal line between public and private will shift over time and with circumstances, not to mention by jurisdiction. ${ }^{36}$ Rather than a weakness on the part of the public domain, however, Deazely is right to assert that this truism underscores the value of contemplating the public domain: because "the private domain of copyright and copyright's public domain necessarily share the same bound-

$31 \mathrm{CCH}$, supra note 21 at para. 22: "in Canada . . copyright protection does not extend to facts or ideas but is limited to the expression of ideas. As such, O'Connor's J. concerns about the 'sweat of the brow' doctrine's improper extension of copyright over facts also resonate in Canada." Copyright Act, supra note 23 at s. 2; defines a compilation to include: "a work resulting from the selection or arrangement of data."

32 Delrina Corp. v. Triolet Systems Inc. (2002), 58 O.R. [3d] 339, [2002] O.J. No. 676, 2002 CarswellOnt 633 (Ont. C.A.); additional reasons at (2002), 2002 CarswellOnt 3220 (Ont. C.A.); leave to appeal refused (2002), 2002 CarswellOnt 4080 (S.C.C.), at para. 52: - "The merger notion is a natural corollary of the idea/expression distinction which ... is fundamental in copyright law in Canada. Clearly, if there is only one or a very limited number of ways to achieve a particular result in a computer program, to hold that way or ways are protectable by copyright could give the copyright holder a monopoly on the idea or function itself."

33 Nichols, supra note 28 - "upon any work, and especially upon a play, a great number of patterns of increasing generality will fit equally well, as more and more of the incident is left out.... [T]here is a point in this series of abstractions where they are no longer protected, since otherwise the playwright could prevent the use of his 'ideas', to which, apart from their expression, his property is never extended."

34 For a recent example of the complexity of ownership issues in the context of compilation copyright, see Robertson v. Thomson Corp., 2006 SCC 43, [2006] 2 S.C.R. 363 (S.C.C.) [Robertson].

35 Deazley, supra note 3 at 131.

36 As Samuelson, supra note 25 at 148 notes, "[t]he public domain is . . different sizes at different times and in different countries." See also Wilkinson, supra note 17 at 28 29 - noting by way of example the dissimilarities between the public domain in the United States and that of Canada in relation to government publications, which are excluded from protection in the former, and subject to Crown copyright in the latter. 
ary", 37 the private domain of copyright is revealed to be as "murky and unknowable" 38 as the public domain. Such contemplation reminds us, then, of the indeterminacy of copyright itself, its dissimilarity to traditional property, and the risks that accompany its reification.

\section{(b) Contested Contiguous Terrains}

Once we reject an absolutist conception of the public domain as containing only those works devoid of protection, the definitional boundaries of the public domain become increasingly contentious. A recurring controversy is whether particular uses of protected works that do not require permission by virtue of exemptions or limitations can themselves be conceptualized as within the public domain. To the extent that the public and the proprietary are regarded as separate and distinct realms, it may seem nonsensical to describe a statutorily permitted use as somehow rendering the protected work as public domain material in a specific instance. ${ }^{39}$ For example, Teresa Scassa, who defines the Canadian public domain as "that which cannot be owned under copyright" 40 insists that the ability to make limited uses of protected works in certain contexts is "a use that is different in character from the use of public domain materials such as facts, ideas, and works in which copyright have expired. Fair dealing operates more like a compulsory licence - the copyright owner is obliged to tolerate certain uses of their copyright protected work in specified contexts." 41

Samuelson's map of the public domain similarly characterizes the public domain as consisting only of "information resources free from intellectual property rights." ${ }^{2}$ Samuelson acknowledges the existence of "a penumbra of privileged uses under fair use, experimental use, and other copyright rules that permit unlicensed uses and sharing of information to take place" that are "outside the public domain in theory, but seemingly inside in effect." ${ }^{43}$ Samuelson depicts these permitted uses as occupying "contiguous terrain" to the public domain. ${ }^{44}$

An alternative definitional approach, however, focuses on uses as opposed to works (or parts of works) as its relevant unit of analysis. Thus, Yochai Benkler

37

Deazley, supra note 3 at 131.

Ibid. at 132 .

Cohen, supra note 2 at 136, describes the perspective of "pro-commodificationists": "[j] ust as the physical public domain lies elsewhere — on the western frontier or preserved behind the carefully delimited borders of national parks and preserves - so too with the intellectual public domain."

Scassa, supra note 16 at 354.

Ibid.

Samuelson, supra note 25 at 151; see also Pamela Samuelson, "Enriching Discourse on Public Domains" (2006) 55 Duke L.J. 101 at 102-103, where she critically examines her original assumption that this is the one correct definition of the public domain, and ultimately concedes, "[a]s I reread the burgeoning public domain literature, I came to see that there are some advantages, as well as some risks, to recognizing the existence of more than one public domain."

Samuelson, supra note 25 at 149.

Ibid. at 151. 
describes the public domain as "the range of uses of information that any person is privileged to make absent individualized facts that make a particular use by a particular person unprivileged." 45 Information in the public domain is, therefore, information "whose use, absent special reasons to think otherwise, is permissible to anyone." 46 In other words, at least with regard to "easy cases" 47 such as the use of short quotes for purposes of critical review, fair use of protected works is within the public domain. ${ }^{48}$ Ronan Deazley also takes a use-based approach, stating that "if the institution of copyright necessitates permission before use, then the public domain allows for use without the need for permission."49 According to Deazley, then, the public domain contains any use for which permission is not required, including use of an insubstantial part of a work, ${ }^{50}$ any statutorily permitted uses such as fair dealing and specified exceptions, for example, educational institutions, libraries, archives, and museums, ${ }^{51}$ and any judicially established limitations on copyright owners' right to control use of the work, such as a use in the "public interest." 52

According to Scassa, the approach that defines all permitted uses as within the public domain "should be a fairly marginal perspective, particularly in the Canadian context, where permitted uses are, for the most part, very narrowly framed and very context specific." 53 As Scassa notes, however, this approach appears to have

45 Yochai Benkler, "Free as the Air to Common Use: First Amendment Constraints on Enclosure of the Public Domain" (1999) 74 N.Y.U.L. Rev. 354 at 362.

Ibid. at 361-362.

47 Ibid. at 362.

48 Benkler's definition does not, therefore, include every privileged use, because some such uses will be difficult cases where the applicability of the statutory exemption is contentious and/or contextually specific.

49 Deazley, supra note 3 at 107.

50 It is only an infringement to reproduce, publish or perform a protected work or a substantial part thereof - Copyright Act, supra note 23 at s. 3. Reproduction of a less than substantial part of a work is considered de minimis and will not infringe copyright. Substantiality is a matter of the quality and quantity of the part taken in relation to the protected work as a whole. See e.g. Francis Day \& Hunter v. Bron, [1963] Ch. 587 (Eng. C.A.).

51 See Copyright Act, supra note 23 at ss. 29-30.9. The fair dealing defence allows users to deal fairly with a work for purposes of criticism, review, research, private study or news reporting. See $\mathrm{CCH}$, supra note 21 (establishing factors relevant to determining whether a dealing is fair).

52 The public interest defence is widely believed to be available in Canada but has not yet been successfully asserted. See R. v. James Lorimer \& Co. (1983), [1984] 1 F.C. 1065, 77 C.P.R. (2d) 262 (Fed. C.A.) - confirming the availability of a public interest defence in proper circumstances against an assertion of Crown copyright. Deazley, supra note 3 at 116-117, citing Ashdown v. Telegraph Group, [2002] Ch 149, also includes within this category uses that must be allowed in light of a user's right to free expression; a similar limitation has yet to be recognized in the Canadian context (see Cie générale des établissements Michelin-Michelin \& Cie v. CAW-Canada (1996), [1997] 2 F.C. 306, 71 C.P.R. (3d) 348 (Fed. T.D.)). 
been endorsed by the Supreme Court of Canada in Théberge, when Justice Binnie wrote, in obiter, that the exceptions to copyright infringement enumerated in the Copyright Act "seek to protect the public domain in traditional ways such as fair dealing for the purpose of criticism or review and to add new protections to reflect new technology, such as limited computer program reproduction and 'ephemeral recordings' in connection with live performances." 54

In my opinion, this was not an unintentional "over-statement" by the Court, 55 but an important conclusion that rightly followed from the Court's statement of copyright's purpose, and its depiction of the public domain. The Court identified the encouragement and dissemination of intellectual works as an important purpose of our copyright system; it has further observed that the public domain performs a crucial role in pursuit of this goal by permitting the incorporation and embellishment of previous creative innovations, thereby fostering future creative innovation. Regarded in this way, the public domain should be understood as the domain of free use and unrestrained creativity, which furthers society's long-term interest in future innovation. And the fair dealing doctrine - which removes copyright constraints by permitting the free use, incorporation, and transformation of other's creative efforts for certain purposes - can be recognized as an essential part of this domain. ${ }^{56}$ When the Supreme Court went on to endorse a vision of fair dealing as a "user right", it completed this picture. ${ }^{57}$ As Drassinower explains: "the conceptual and terminological shift in $\mathrm{CCH}$ from fair dealing as an exception to fair dealing as a user right evidences an orientation bent upon undoing the systematic exclusion of the public domain. . . . Under this view, the public domain is irretrievably central to copyright." 58

A further controversy simmering at the definitional margins of the public domain concerns the place of open source and free software movements ${ }^{59}$ and initia-

$54 \quad$ Théberge, supra note 18 at para. 32.

55 Cf. Scassa, supra note 16 at 354 - "It is not clear ... whether the comments in Théberge reflect a change in Canadian law or an over-statement by the Court of the concept of the public domain."

56 For further discussion of the role of fair dealing in advancing the purposes of the copyright system, see Carys J. Craig, "The Changing Face of Fair Dealing in Canadian Copyright Law: A Proposal for Legislative Reform" in Michael Geist, ed., In the Public Interest: The Future of Canadian Copyright Law (Toronto: Irwin Law, 2005) 437.

$57 \mathrm{CCH}$, supra note 21 at para. 12, McLachlin C.J.C. - "The exceptions to copyright infringement, perhaps more properly understood as users' rights, are set out in ss. 29 and 30 of the Act."

58 Abraham Drassinower, "Authorship as Public Address: On the Specificity of Copyright Vis-á-vis Patent and Trademark” (2008) 1 Mitch. St. L. Rev. 199 at 202.

59 Maurice Schellekens, "Free and Open Source Software: An Answer to Commodification" in L. Guibault \& P.B. Hugenholtz, eds., The Future of the Public Domain: Identifying the Commons in Information Law (Netherlands: Kluwer Law International, 2006) 303 at 304-305, explains that the difference between the Open Source Initiative and the Free Software movement is primarily one of ideological background, with the former being driven by practicality and pragmatics, while the latter is focused on freedom as an motivating ideal. Both movements are rooted in the belief that rigorous copyright laws suppress creativity and innovation in the software industry. 
tives such as Creative Commons; it is not clear whether, or to what extent, content distributed under such models can be conceptually located within the public domain. In the open source model, the source code of computer software is made available to the public; however, the use or modification of the code is subject to the terms of the applicable license, which typically obliges the licensee to make downstream code and derivative works publicly available, and to impose the same terms on subsequent licensees. ${ }^{60}$ In other words, it is only by virtue of the existence and consistent assertion of intellectual property rights that the open source system can operate. 61

Similarly, the Creative Commons movement seeks to promote the sharing and reuse of informational works through an innovative use of traditional intellectual property and contract law. Founded in 2001, the organization seeks to define "the spectrum of possibilities between full copyright - all rights reserved - and the public domain - no rights reserved." 62 It uses an automated licensing platform that enables authors to easily share their works under more generous terms, with the objective of restoring "balance, compromise, and moderation" to the copyright system. Like open source, the Creative Commons is therefore "completely dependent upon a proprietary regime and derives its force from its existence."63

Samuelson's map, again, places open source software in the territory "adjacent" to the public domain. ${ }^{64}$ Samuelson explains that open source software and $\mathrm{CC}$-licensed content are not public domain in the sense of being unencumbered by intellectual property rights, as these rights are the very source of authority for the license terms under which this content is made widely available. ${ }^{65}$ Scassa agrees

60 See ibid. at 304-309. The archetypal example is the General Public License, available online: <http://www.gnu.org/copyleft/gpl.html>.

61 Schellekens, Ibid. at 309-310, writes: "So where do we position open source? The free and open source movements are a reaction against software enclosure, but free and open source software are not in the public domain; their 'openness' is based on intellectual property licenses. Although copyright and the possibility to withhold source code from the users of information create an excellent position to exercise exclusion, this does not happen. Open source is 'free' and the position of power, which is meanly derived from copyright, is used to keep it free."

62 Creative Commons: "About", online: Creative Commons $<$ http://creativecommons.org/about/>.

63 Niva Elkin-Koren, "Exploring Creative Commons: A Skeptical View of a Worthy Pursuit" in L. Guibault \& P.B. Hugenholtz, eds., In the Future of the Public Domain (Netherlands: Kluwer Law International, 2006) 325 at 325. Elkin-Koren warns that the ideological mission of the movement is poorly served by the libertarian sentiment of letting owners rule their property however they choose. In the absence of a standardized license terms such as those developed in free software's General Public License, the discretionary tools of Creative Commons do not guarantee increased freedom to use.

64 Samuelson, supra note 25 at 151.

65 Samuelson, supra note 42 at 123 ; see also Boyle, supra note 8 at 65 - "neither "free software,' nor most 'open-source software' is in the public domain. After all, the thing that makes open-source software work is the General Public License." 
that including such works within the public domain is "a stretch" since copyright is being asserted, "albeit in a user-friendly way."66

Other commentators, however, have argued or simply assumed that these innovative attempts to reclaim proprietary constructs for the purpose of public dissemination and use are essentially public domain projects. ${ }^{67}$ This position clearly departs from "the old dividing line in the literature on the public domain ... between the realm of property and the realm of the free", and assumes a new, but similarly significant divide, perhaps between "the realm of individual control and the realm of distributed creation, management, and enterprise." 68 Open source and Creative Commons content is deemed to be at least functionally equivalent to public domain material because it furthers the goals of wide dissemination and use. Whether such materials are included in the definition of the public domain will depend on whether that definition is drawn on legalistic, political, or aspirational lines. But, as Samuelson ultimately concedes, "even those who might question whether contractually constructed commons should be included in a definition of public domain would likely agree that such commons promote public domain values." $" 69$

\section{CONCEPTIONS OF THE (MANY) PUBLIC DOMAIN(S)}

\section{(a) Legal Realism for the Public Domain}

This lack of definitional clarity may appear to be symptomatic of an inherent weakness in the concept of the public domain: if we cannot agree upon the contents and scope of the public domain, then must we concede that it is simply "too slippery, too imprecise to warrant any coherent and detailed consideration"? ${ }^{70}$ On the contrary, perhaps it is because of - and not in spite of - this definitional ambiguity that the public domain concept is so potentially useful in the political struggle over copyright law and its limits.

As James Boyle explains, how we choose to define the substance and scope of the public domain "depends on why we care about the public domain, on what vision of freedom or creativity we think the public domain stands for, and what danger it protects against. The public domain will change its shape according to the hopes it embodies, the fears it tries to lay to rest, and the implicit vision of creativity on which it rests. There is not one public domain, but many."71 The recognition of multiple public domains may present some risk of confusion or miscommunica-

66 Scassa, supra note 16 at 353.

67 See e.g. David Bollier, Why the Public Domain Matters: The Endangered Wellspring of Creativity, Commerce, and Democracy (Washington, DC: New American Foundation and Public Knowledge, 2002) at 14; Robert P. Merges, "A New Dynamism in the Public Domain” (2004) 71 U. Chicago L. Rev. at 190-193.

Boyle, supra note 8 at 66 .

Samuelson, supra note 42 at 124.

Deazley, supra note 3 at 105 , describes this as the "already prevalent perspective of the public domain."

Boyle, supra note 8 at 62. 
tion, ${ }^{72}$ but it also promises a richer discussion, for it requires us to consider and acknowledge the political purpose motivating our definitional approach. ${ }^{73}$ This is legal realism for the public domain: ${ }^{74}$ the public domain is revealed to be nothing more or less than "a social-legal construct" 75 whose purpose is "to assist us in thinking of a complex issue, to organize our thoughts, to serve as a 'short cut' to denote a mindset, a view, a perception." 76 Rather than spilling ink or its virtual equivalent on definitional quandaries, our energies can be spent articulating political goals and exploring the legal and practical tools that may enable their attainment. $^{77}$

Pamela Samuelson responded to Boyle's acceptance of "many" purposively drawn "public domains" by attempting to identify the multiple versions appearing in the literature, and to organize them into conceptual categories. Samuelson identified thirteen versions in all, from the negatively drawn "information artifacts wholly free from intellectual property rights" to the "contractually constructed information commons"; from the "constitutionally mandated public domain" to the "privatizable public domain"; and from "broadly usable information resources" to the "unpublished public domain." Ultimately, Samuelson proposed three thematically coherent definitional clusters: those concerned with the legal status of information resources; those focused on freedoms to use information resources; and those which stress the accessibility of information resources. ${ }^{78}$ Thus, for example, the public domain of IP-free information resources belongs in the first cluster concerned with identifying legal status; the domain of broadly usable information resources, as well as privileged uses of IP-protected works, cluster around the question of freedom to use, and definitions that focus on the scientific "commons" or the undisclosed public domain cluster around the theme of public accessibility.

From this clustering process, Samuelson draws lessons for public domain theorizing. First, we can see that the most robust public domains are those which are free of intellectual property encumbrances while also being widely accessible to the public. ${ }^{79}$ Second, we can more readily acknowledge that the public domain may be best understood as a continuum of legal states on a spectrum that ranges between information resources subject to the most restrictive legal encumbrances (intellec-

72 Samuelson, supra note 42 at 103, 164-165.

73 Ibid. at 104 - "The principal advantage of recognizing multiple public domains is that it illuminates a range of important social values served by these domains and a plethora of strategies for preserving them and the values they serve."

Boyle, supra note 8 at 67.

75 Samuelson, supra note 42 at 145.

76 E-mail from Michael Birnhack to Pamela Samuelson (October 28, 2005), quoted in Samuelson, ibid. at 145.

77 Samuelson, supra note 42 at 155-157, describes the benefits of accepting multiple public domains: avoiding likely fruitless debates over which definition is correct; broadening awareness of public domain values; developing context-sensitive uses of the public domain; and enabling more nuanced answers to our questions about the public domain and its fate. 
tual property rights, contractual limits, and technological protection measures) to the least restrictive (free of intellectual property rights, and subject to positive even constitutional — rights of public access and use). Guided by different concerns, driven by different goals, different commentators will draw the line for their public domain at different points on the spectrum between absolute freedom and access and absolute control. Fundamentally, this reveals the need for a nuanced and complex discourse around a pragmatic public domain concept that moves beyond a simple public/private dichotomy.

At the outset of this article, I claimed that the public domain means "whatever we want it to mean", and implied that, however we define it, it should be equipped to hold back the tide of intellectual property expansion. It should now be clear that form follows function. ${ }^{80}$ We need the public domain to be capable of many functions in the performance of its political role: "as a building block for the creation of new knowledge, and as an enabler of competitive imitation, follow-on creation, free or low cost access to information, public access to cultural heritage, education, self-expression and autonomy, various governmental functions, or deliberative democracy." 81 In the discussion that follows, I highlight some critical contributions to the public domain discourse with a view to supporting a dynamic formulation of the public domain that situates it in the context of creative processes and cultural participation and, therefore, at the heart of copyright policy.

\section{(b) Toward a Dynamic Public Domain of Creative Use}

A legalistic definition of the public domain limited to IP-free information resources risks depicting the public domain as nothing more than "the other side of the coin of copyright [that] is best defined in negative terms." 82 In this light, it comes to be seen as "the realm of material that is undeserving of protection" 83 or worse, it is at risk of not being seen at all; it is rendered "the invisible Other." 84 If the public domain is regarded as little more than "a virtual wasteland of undeserving detritus", 85 then the prevailing assumption will be that anything of value within that realm ought to receive the recognition of propertization. ${ }^{86}$ After all, as Jane Ginsburg has noted, even the common expression "to fall into the public domain"

80 Boyle, supra note 8 at 61.

81 Ibid. at $158-159$.

82 M. William Krasilovsky, "Observations on Public Domain" (1967) 14 Bulletin of the Copyright Society of the U.S.A. 205 at 205.

83 Litman, supra note 26 at 967.

84 Boyle, supra note 8 at 69

85 Samuelson, supra note 25 at 147 - "Whether the public domain is a virtual wasteland of undeserving detritus or the font of all new creation is the subject of some debate. Those who adhere to the former perspective do not worry about 'threats' to this domain any more than they would worry about scavengers who go to garbage dumps to look for abandoned property."

86 Litman, supra note 26 at 967 - observing that the description of public domain material as "uncopyrightable" inspires the question "why not?" 
pointedly evokes "the devastation of a fall from grace", 87 suggesting a sense of both loss and waste inherent in depropertization. ${ }^{88}$

Julie Cohen describes a "cultural stewardship model" of the public domain, adherents to which regard ownership as the prerequisite of productive management. From this it follows that "[p]assage into the public domain should occur only after the productive life of a cultural good has ended, and is to be mourned, not celebrated." 89 Conceptualized negatively, the public domain is situated "outside" of copyright; it is "systematically excluded" 90 from copyright law and largely deprived of normative significance. As Lange observes, this is one of the "least useful or persuasive notions" of the public domain because it fails to attribute to the public domain "an affirmative existence of its own." 91 It has no political capacity to counter the excesses of propertization, because its contents are always susceptible to the privatization rationale.

Juxtaposed with this cultural stewardship model of the public domain is what Cohen calls the "conservancy model." So-called conservancy theorists are concerned with ensuring the growth of the public domain and its protection against threatened incursions. ${ }^{92}$ Lange, who arguably spearheaded the conservancy model, thus appealed for the recognition of the public domain as a "place of sanctuary for individual creative expression" that confers "affirmative protection against the forces of private appropriation." 93 Lange's public domain is not merely the obverse of intellectual property, but a matter of public entitlement that must be conceptualized in positive, indeed political, terms.

The emergence of an affirmative public domain discourse has been closely tied to the critical reconceptualization of original authorship in copyright scholarship. In 1991, Jessica Litman's important contribution to the development of "a theory of the public domain" drew the link between the fiction of originality and the function of the public domain..$^{94}$ The role and relevance attributed to the public domain in copyright law was shown to be intricately connected to the notion of creativity as origination that it assumes. Litman argued that authorship is not a process of original creation out of nothing, but rather involves the absorption and recombination of raw materials that the author has encountered in pre-existing

87 Ginsburg, supra note 5 at 668.

88 Cohen, supra note 2 at 134 - noting that "the metaphor of 'falling' into the public domain ... conveys this sense of loss and waste."

89 Ibid. Cohen identifies the most prominent adherents to this school as economic theorists William Landes and Richard Posner. See William Landes \& Richard Posner, The Economic Structure of Intellectual Property Law (Cambridge, MA: Harvard University Press, 2003). Boyle, supra note 8 at 40, also criticizes the common assumption in economic theorizing that any commons is inefficient, and the attendant implication that opposing the expansion of intellectual property is "economically illiterate."

90 Drassinower, supra note 58 at 202.

91 Lange, supra note 1 at 473.

92 Cohen, supra note 2 at 133-134.

93 Lange, supra note 1 at 466.

94 Litman, supra note 26. 
works; 95 it is therefore only by virtue of the public domain concept that copyright can function in spite of its fallacies. Litman explains: "[t]he public domain rescues us from this dilemma. ... It furnishes a crucial device to an otherwise unworkable system by reserving the raw material of authorship to the commons, thus leaving the raw material available for other authors to use." 96 From this perspective, the public domain is essential to the processes of authorship and, therefore, central to a copyright system whose objective is to encourage authors to create.

Building on this insight, several copyright scholars critically examined the "romantic author" who occupied the protagonist's role in copyright discourse, and revealed the significance of "author reasoning" in the diminution and marginalization of the public domain. ${ }^{97}$ Stripped of his romance, the author was revealed to be dependent upon others' work for inspiration and material, and the public domain was hailed to be the intellectual commons from which s/he must draw. In other words, without the fiction of original creation, the public domain could be recognized as the domain of creative use in which real authors must be free to play. 98

Even this picture of the public domain, however, may be thought to lack the vibrancy and dynamism that conservancy advocates increasingly hope to capture. The problem, perhaps, is the manner in which the organizing metaphor posits the public domain as a discrete preserve, for all purposes notionally equivalent to a geographical space in which the public freely roam. An increasingly complex understanding of the cultural and cumulative processes of creativity suggests a vision of the public domain absent such static boundaries. In 2003, David Lange argued that the metaphor of place is no longer — and probably never was - sufficient to describe the public domain from the perspective of creativity. ${ }^{99}$ According to Lange, a better metaphor than place is status: "[i]magine the public domain as a status that arises from the exercise of the creative imagination, thus to confer entitlements, privileges and immunities in the service of that exercise; a status independently and affirmatively recognized in law, sometimes collective in nature and sometimes individual, but omnipresent, portable, and defining; and a status mean-

$95 \quad$ Ibid. at 998.

96 Ibid. at 1023. Litman, Ibid. at 967, explains: "the public domain is law's primary safeguard of the raw material that makes authorship possible."

97 Boyle, supra note 8 at 51, concisely explains the connection between the ideal of original creation ex nihilo and our assumptions about the public domain: "[w]ho needs a public domain if you can create out of nothing?"; See also, James Boyle, Shamans, Software, \& Spleens: Law and the Construction of the Information Society (Massachusetts, U.S.: Harvard University Press, 1996); Keith Aoki, "Authors, Inventors, and Trademark Owners: Private Intellectual Property and the Public Domain (Part I) (1993) 18 Colum-VLA J.L. \& the Arts 1; Peter Jaszi, "On the Author Effect: Contemporary Copyright and Collective Creativity" (1991) 10 Cardozo Arts \& Ent. L.J. 293 at 293.

98 Lange, supra note 1 at 470 - "In this way the public domain itself could become a place of refuge for creative expression, a place of individual no less than collective entitlement, dimensioned both physically and conceptually, and sanctioned by law. In short, the public domain would be a place like home, where, when you of there, they have to take you in and let you dance." 
while paramount to whatever inconsistent status may be conferred upon a work of authorship (or its author) from time to time. ..."100

It is this public domain status, according to Lange, that will allow us to more clearly understand the protection that exercises of the creative imagination require, and so to deploy the public domain against the encroachments of intellectual property upon creative activity. ${ }^{101}$ Thus, for example, fair dealing would be an aspect of the public domain and any creative appropriation presumptively privileged. ${ }^{102}$ Lange's conception of public domain as status is founded on a recognition of the creative process as a vital aspect of our citizenship and human experience; the role of the public domain is to secure our innate aspirations "to think and to imagine, to remember and appropriate, to play and to create."103

Julie Cohen shares Lange's perception of the public domain as vital to creativity and, in turn, of creativity as a social phenomenon vital to the self-actualization of the situated author. ${ }^{104}$ Cohen appeals to a conception of the public domain guided by "a sociology of creativity" rooted in "the day-to-day realities of creative practice." 105 Pointing to the socially embedded nature of the creative process, Cohen similarly takes issue with the implications of the public domain metaphor. Drawing connections between copyright's "public domain" and that of U.S. land law (a government holding device for land destined for private appropriation), she shows how our chosen metaphor complicates the political task of copyright's public domain advocates. Cohen appeals to "a different type of spatial metaphor" that more accurately reflects the realities of creative practices, ${ }^{106}$ namely, the "cultural landscape."

According to Cohen's cultural landscape model, public entitlements to access that engage with, and borrow from the cultural landscape cannot be contained within an ontologically separate entity called the public domain. Rather than reifying this domain, then, we should reformulate it to reflect a cultural commons that is distributed and disaggregated, ${ }^{107}$ dynamic and relational. ${ }^{108}$ The cultural landscape is not defined by ownership but by the experience and participation of the creators who draw on its resources, and the public domain, as "a distributed property of social space", is part of that landscape. This reformulation shifts our atten-

100 Ibid.

101 Ibid. at 476.

102 Ibid. at 479-481; see also David Lange \& Jennifer Lange Anderson, "Copyright, Fair Use and Transformative Critical Appropriation" (Paper presented at the Conference on the Public Domain at the Duke Law School, 9-11 November 2001), online: Duke Law School <http://www.law.duke.edu/pd/papers/langeand.pdf $>$ at 151 - "If critical transformation begets fair use, then the exclusive rights must gracefully step aside pro tanto."

103 Lange, supra note 1 at 483.

104 Samuelson, supra note 42 at 129, 132, draws comparisons between Lange and Cohen's work.

105 Cohen, supra note 2 at 146.

106 Ibid. at 137.

107 Ibid. at 166

108 Ibid. at 158 . 
tion back to the public's relationship with cultural resources and the social reality of creative borrowing, thereby bringing into relief the impact of copyright on creative practice, ${ }^{109}$ and the necessary limits of commodification. ${ }^{110}$

Finally, Michael Birnhack is similarly concerned with creativity as a relational and communicative enterprise, with "a crucial role in personal self-development, learning, experiencing, imagining, speaking with others, creating new works for the benefit of ourselves and wider circles, starting from the immediate interlocutor and up to the entire community." 111 The public domain is central to this deliberative enterprise because "it is where knowledge is created and where it lies awaiting new interpretations, new applications and new meanings." ${ }^{112}$ Birnhack, therefore, envisages the public domain as human entitlement equivalent in nature, purpose, and importance to the freedom of speech. Once again, a vision of authorship as discursive participation, as opposed to simple origination, necessitates a rich conception of the public domain in which participants can join in and build on existing works, but also reuse and reproduce works in a way that changes their meaning. ${ }^{113} \mathrm{Be}$ cause copyright, as a form of cultural control, interferes with exchange in the communicative sphere, Birnhack's democratic (indeed constitutional) account of copyright demands that it does so with the aim and result of improving the quality of public discourse and generating a better, richer and more diverse, public domain. ${ }^{114}$

Samuelson includes the work of Lange, Cohen and Birnhack in a cluster focused on the freedom to use information resources even when works embodying these resources are protected by intellectual property rights. ${ }^{115}$ She goes on to laud the public domains articulated by these three as "among the most imaginative and inspiring public domains in the literature", explaining: "[f]rom their work, readers should take away a more dynamic and vibrant sense of the role of public domains

109 Ibid. — "Commodification radically alters the public's relationship with the cultural landscape because it systematically reverses all of the implicit presumptions that individuals have historically brought to their experience of and participation in the development of culture."

$110 \mathrm{Ibid}$. at 150 - "copyright as incompletely commodified by design and more fundamentally by necessity."

111 Michael D. Birnhack, "More or Better? Shaping the Public Domain" in L. Guibault \& P.B. Hugenholtz, eds., The Future of the Public Domain (Netherlands, Kluwer Law International, 2006) 59 at 60.

112 Ibid.

113 Ibid. at 85

114 Ibid. - "both copyright law and free speech jurisprudence aim at a rich and diverse public domain, in which deliberation can take place without any impediments, in which all who wish can participate, regardless of their market power. It is a public domain which is interested in the exchange between the multiple voices and their expressions, which realized that new ideas form when old ideas interact. In other words, this is a public domain that rejects cultural control, which is executed through the use of property rights; it is a public domain that is required by the best reading we can offer for ... copyright law."

115 Samuelson, supra note 42 at 146. 
in creative work and public discourse." 116 In my opinion, it is in this dynamic vision of the public domain - as central to the creative and communicative practices that define our sense of self and society - that we see the potential power of the public domain concept to shape copyright policy in the digital era, from the inside out.

\section{(c) A Public Domain Discourse for Canada}

This is a critical moment in Canadian cultural life. New networked technologies present unprecedented opportunities for creative expression, critical engagement, and participation in public discourse. But, these technologies are subject to social regulation and cultural controls, often in the form of legal proprietary regimes that allocate rights of exclusivity over information resources and so, restrict their creation, circulation and management. Copyright law, in particular, has arrived at a crossroads where it suddenly seems that a choice must be made between maximizing the potential of the digital revolution and reinforcing the norms of the analogue world. Thankfully, this is a false dilemma: copyright policy contains within it the norms and aspirations that, not only permit, but necessitate the development of a robust public domain in which citizens freely participate - a domain made more open, accessible, democratic, and vital by the advances of network technologies.

The copyright system should be regarded as one element of a larger cultural and social policy aimed at encouraging the process of cultural exchange that new technologies facilitate. The economic and other incentives that copyright offers to creators of original expression are meant to encourage a participatory and interactive society, and to further the social goods that flow through public dialogue. Copyright's purpose is to create opportunities for people to speak, to develop relationships of communication between author and audience, and to fashion conditions that might cultivate a higher quality of expression. ${ }^{117}$ The public domain that is irreducibly central ${ }^{118}$ to the copyright system protects the cultural space in which this happens.

In Canada, there is some cause to be optimistic; the Supreme Court has already sketched a picture of a robust public domain that can "incorporate and embellish creative innovation in the long-term interest of society as a whole" 119 and "help foster future creative innovation." 120 In Robertson v. Thomson Corp., Justice Abella considered copyright's capacity to "keep pace with technological developments to foster intellectual, artistic and cultural creativity", and stated that, in fac-

116 Ibid. at 167 - Samuelson continues: "Their conceptions of the public domain ... aim to expand the bounds of this domain so that appropriations from preexisting works will more often be deemed legitimate reuse of ideas, rather than an improper appropriation of expression, from protected works."

117 For a more expansive description and justification of this vision of copyright's purpose, see Carys J. Craig, "Putting the Community in Communication: Dissolving the Conflict Between Freedom of Expression and Copyright" (2006) 56 U.T.L.J. 75.

118 See Drassinower, supra note 58 at 202.

119 Théberge, supra note 18 at para. 32.

$120 \mathrm{CCH}$, supra note 21 at para. 23. 
ing the challenges of regulation in this context, "the public benefits of this digital universe should be kept prominently in view." ${ }^{21}$ Citing Michael Geist, the minority judgment continues: "[t]he Internet and new technologies have unleashed a remarkable array of new creativity, empowering millions of individuals to do more than just consume our culture, instead enabling them to actively and meaningfully participate in it." 122 Such statements seem to hold promise of a copyright system that respects and reflects the transformative possibilities of new technologies rather than resisting and constraining the emerging cultural practices that these technologies permit.

This promise, however, is increasingly remote; so, too, is the vision of the public domain that is essential to such a system. The existing sketch must be filled in with firm strokes or risk erasure. Threats to the Canadian public domain are too many and too varied to canvass here, but it is worth mentioning a few that are pertinent to the copyright reform process currently underway. In addition to the legal, economic, and transactional obstacles of intellectual property, the value of the public domain is subject to the physical and technological barriers that can prevent access to even IP-free information resources. In order to occupy its central role in cultural practices, the public domain must be practically accessible to creative actors; but rather than protecting the rights of the public to access and use resources in the public domain, proposed reforms move to protect the right to lock-up these resources. ${ }^{123}$ Acts permitted in relation to owned content - users' rights to read, listen, research, study, criticize, transform - can be prevented by the use of tech-

121 Robertson, supra note 34 at para. 79; Ibid. at para. 49 - tempering this optimism somewhat, it should be noted that these statements were made by Justice Abella in the context of a minority opinion. The majority appeared less concerned with ensuring that copyright not interfere with the advantages offered by new technologies: "[m]edia neutrality is not a licence to override the rights of authors - it exists to protect the rights of authors and others as technology evolves."

122 Michael Geist, Our Own Creative Land: Cultural Monopoly \& The Trouble With Copyright (Toronto: Hart House Lecture Committee, 2006) at 9, cited in Robertson, supra note 34 at para. 79.

123 WIPO Copyright Treaty, 20 December 1996, WO033EN at Art 11, states: "Contracting Parties shall provide adequate legal protection and effective legal remedies against the circumvention of effective technological measures that are used by authors in connection with the exercise of their rights under this Treaty or the Berne Convention and that restrict acts, in respect of their works, which are not authorized by the authors concerned or permitted by law." Bill C-61, the latest copyright reform bill to be tabled in Canada, contained provisions making unlawful the circumvention of TPMs, and the offering of services or distribution of technology for the purpose of circumventing TPMs (s. 40.1). Exceptions did not include circumvention for the purposes of lawful or permitted uses of underlying content. See Bill C-61, An Act to amend the Copyright Act, 2nd Sess., 39th Parl., 2008, Cl. 31 (as dissolved upon the dissolution of the 39th Parliament). Cf. Bill C-60, An Act to amend the Copyright Act, 1st Sess., 38th Parl., 2005 (as dissolved upon the dissolution of the 38th Parliament); For a detailed discussion of the tension between anti-circumvention laws and the public domain, see Carys J. Craig, "Digital Locks and the Fate of Fair Dealing in Canada: In Pursuit of 'Prescriptive Parallelism"” (forthcoming, World Journal of Intellectual Property, 2010). 
nological protection measures, and potentially rendered unlawful by imminent anticircumvention provisions.

Where copyright and technological barriers do not suffice, the norms of contract law can step in to further limit users' activities; generic "click-through" contracts place still more restrictions on the public's enjoyment of resources in the cultural landscape, effectively supplanting so-called user rights and the public domain. Rather than attempting to protect the public domain against these incursions, proposed legislation makes explicit the priority of contractual obligations. ${ }^{124}$ Even proposed additions to statutory exceptions available for users, educational institutions, libraries and museums are so narrowly drawn, and subject to such rigorous provisos that they are more indicative of a constriction and marginalization of the public domain than its protection. ${ }^{125}$ Moreover, it is important to bear in mind not only the potential application of a revised copyright law, but the perception of increased regulation and criminalization that these legal reforms generate. As Deazley reminds us, "in practice, the manner in which [the public domain] functions is bound up in individual perceptions of the way in which people can or cannot use those cultural products to which they have access." 126

In the rush to respond to the "challenges" of the digital age, copyright reforms threaten to reduce the shape and operation of the public domain in the name of furthering copyright's policy goals. This fails to reflect the centrality of the public domain to copyright and broader cultural policy, exemplifying its fragility when conceptualized merely as the absence of proprietary control and value. But, if perception and practice are as intertwined and mutually supportive as Deazley suggests, then each presents its own opportunities for resistance. Practically, the dynamic fair dealing practices undertaken every day by Canadian users, researchers, librarians, students, journalists, historians, documentarians, archivists, and other cultural actors, can effectively support and expand the Canadian public domain; ${ }^{127}$ but in terms of perception, these practices must be complemented by the affirmative understanding and discourse of the public domain canvassed here - one that recognizes it as a source of public entitlement, and as a vital part of our cultural landscape.

124 Newly drafted exceptions in Bill C-61 are expressly subject to any contractual obligations undertaken. See, e.g. Bill C-61, at Cl. 17. The priority of contract was also made explicit by the Supreme Court of Canada in Robertson, supra note 34 at para. 58 "Parties are, have been, and will continue to be, free to alter by contract the rights established by the Copyright Act."

125 See Bill C-61, ibid. at Cls. 17-21. As a result of the "exceptions to exceptions", each of these provisions runs to a length beyond that which can be appropriately reproduced in an endnote.

126 Deazley, supra note 3 at 118.

127 See Rosemary Coombe \& Darren Wershler-Henry, eds., Dynamic Fair Dealing: Creating Canadian Culture Online (forthcoming). 


\section{CONCLUSION}

The ownership and control of information resources is one of the most important forms of power in contemporary society. ${ }^{128}$ Digital technologies, therefore, have the potential to alter and subvert power structures by changing the ways in which we access, engage with, and participate in the creation of these resources. By the same token, intellectual property laws have the capacity (to a greater or lesser degree) to shore up existing power structures and limit creative practices by enforcing and expanding traditional proprietary norms in the digital environment.

James Boyle has argued that we are in the midst of a "second enclosure movement" where the commons of facts, ideas, and other previously unprotectable subject matters is being enclosed by an intellectual property system that assumes that more property is better. ${ }^{129}$ The expansion of intellectual property is not only formal but also practical. As Boyle explains, in a networked society, digital reproduction blurs the lines between communication, storage, recreation, and reproduction, such that "the reach of the rights has been expanded at the same moment that their practical effect has been transformed." 130 In response to this threat, Boyle called for a new form of "environmentalism" for the Net: a unifying idea that can add a moral overtone to our discussion about intellectual property and the public domain; an insistence that there are larger structural reasons for our failure to preserve the public domain as a whole; a rallying cry that brings together the voices that disparately protest the gradual chipping away of the public domain. The concept of the public domain may be used in multiple and overlapping ways by various parties with divergent interests, but it nonetheless has the power to help us "reimagine creation, innovation, and speech on a global network." 131 However, Boyle reminds us, it "must be 'invented' before it is saved." 132

The public domain has not received much attention from Canadian scholars, judges, or policy-makers, and has typically been mentioned, if at all, only in passing, as though its meaning were self-evident. Presumably, the operating assumption has been that the public domain is no more and no less than that to which intellectual property rights do not attach. I hope that this essay has shown the public domain to be a far more nuanced, compelling, contested, and potentially useful concept than this inattention would suggest. Conceptualized as a vibrant, dynamic, and shifting space in which citizens freely engage in communicative and creative activities, the public domain takes on a positive dimension and a political power. This power can, and must be harnessed to challenge the expansion of intellectual property and its paradigms of control and exclusivity in our networked society.

128 James Boyle, "Politics of Intellectual Property: Environmentalism for the Net?" (1997) 47 Duke L.J. 87 at 87 - "Everyone says that we are moving to an information age. Everyone says that the ownership and control of information is one of the most important forms of power in contemporary society. These ideas are so well-accepted, such clichés, that I can get away with saying them in a law review article without footnote support." The irony of this footnote is not lost on me. 